\title{
The Relationship between Institutional Capital and Competitive Advantage: Literature Review and Future Research
}

\author{
Manli Huang, Lihua Cao \\ School of Business Administration, South China University of Technology, Guangzhou, China \\ Email:caolihua2010@foxmail.com
}

Received 11 December 2015; accepted 15 January 2016; published 18 January 2016

Copyright $(\subseteq 2016$ by authors and Scientific Research Publishing Inc.

This work is licensed under the Creative Commons Attribution International License (CC BY). http://creativecommons.org/licenses/by/4.0/

(c) (i) Open Access

\begin{abstract}
The conception of institutional capital was first raised by Oliver, integrating resource-based view with institutional theory, which provided new theoretical explanation for the source of competitive advantage. Through extensive literature review, this paper sorts out the definition of institutional capital and explores the paths form institutional capital to competitive advantage based on four characteristics of strategic resources. It points out the directions for future research and puts forward a logic framework and theoretical innovation space in Chinese context.
\end{abstract}

\section{Keywords}

Institutional Capital, Competitive Advantage, Resource-Based View, Institution-Based View

\section{Introduction}

The source of competitive advantage is one of the most important research topics in the field of strategic management [1] [2]. Scholars explore and analyze the theme from different theoretical perspectives, which contribute to diversified theory genres that different from each other. In general, these theory schools can be divided into three categories. One thinks competitive advantage stems from the internal resources and capabilities that enterprises have [3], during which resource-based view (RBV) is the most systematic perspective. Another perspective attributes the competitive advantage to enterprises' external environment [4] [5]. The third perspective attaches particular importance to the internal and external institutions, which is the core proposition of the newly emerging institutional-based view (IBV).

Oliver, C. (1997) put forward the concept of "institutional capital" by integrating resource-based view and institutional theory [6]. She thinks an institutional environment has important influence on enterprises' selection 
process of strategic resources, heterogeneity and sustainability of competitive advantage. In other words, enterprises can gain competitive advantages through the effective management of institutional environment. Institutional capital is embedded in the environment where enterprises operate and it is able to enhance competitive advantages by strengthening the resources allocation ability. At the same time, institutional theory has been introduced into strategic management research more and more thoroughly. The dynamic interaction between institutions and organizations as well as the influence on strategic choice of such interaction has become a hot issue in strategic area. Peng, M. K. et al. (2002) propose institution-based view, which thinks strategic choice is not only determined by enterprises' resources and abilities, but also reflects enterprises' behavioral preference facing the formal and informal restrictions of certain institutional framework [7]. That is to say, institution is not only regarded as the exogenous variable of the enterprises' choice and action background, but also the important endogenous variable for developing a strategy and gaining competitive advantages. Bresser, R. and Molling, K. (2003) expand the idea of Oliver, they think the way institutional capital affects competitive advantage not only reflects in the resource decision-making, but also many aspects of decision-making behaviors and organization's strategic choice [8]. They discuss relationship between institutional capital and competitive advantage from a broader range. However, as the dilemma that institutional theory faced in the field of strategic management, the conceptualization and practical operation of institutional capital is still vague, which greatly limits its further development. The paper tries to open the "black box" in order to improve the answer to the source of competitive advantage, which is a fundamental question for the enterprise, focusing on the relationship between institutional capital and competitive advantage from both resource-based view and institutional-based view.

The rest of the paper is organized as follows. The next section reviews the different concept definition of institutional capital from both macro and micro insights, followed by discrimination towards diversified definitions. The third section discusses the relationship between institutional capital and competitive advantage based on the four characteristics of strategic resources. Next, it reviews the existing measuring methods of institutional capital. Theoretical shortcomings as well as future research directions are provided in the last section.

\section{Definition of Institutional Capital}

In the paper "Institution and the Rising Economic Value of Man”, Schultz, T. W. (1986) thinks that people are trying to make wise social choice by considering the alternative institutional change, to enhance economic efficiency and performance of economic welfare [9]. The paper has proven that institution has economic value, which is almost the earliest exposition of institutions' economic efficiency and this lays a logic foundation for the transform from institution to institutional capital. Thanks to the research of Bresser, et al. (2003), institutional capital as a concept of strategic management has begun to gain attention and application. They think it is not enough to study institutional capital only from the process of resource selection, while the role of institutional environment played in the formation of competitive advantage has been neglected for a long time. Therefore, they differentiate and analyze three levels' formation mechanisms of institutional capital, and construct a comprehensive model integrating strategic management and new institutionalism. As institutional elements are introduced into the research on strategic management continually, many scholars have proposed that institutional capital has an important influence on the development of political and economic development of modern society [10]. However, the development of research on institutional capital is still very slow in this context. Although it has been a dozen years since Oliver first raised the concept of institutional capital, scholars still can't reach an agreement on the definition of institutional capital. The present conception of institutional capital can be divided into two perspectives, one defines institutional capital from micro level, paying attention to corporate strategic management and competitive advantage acquisition. These definitions regard institutional capital as the resource, capacity or environmental factors embedded in the enterprises' institutional environment that can improve value-added assets and competitiveness, which extends the connotation of institutional capital based on original definition proposed by Oliver. Another defines it from a macro level and attaches significant importance to national economic institution and political institution. These scholars define institutional capital as "superiority" resulted from national institution. That is to say, the national economic and political environment creates a comparative institutional advantage for citizens and organizations of this country. The main definitions of institutional capital are shown in Table 1.

\subsection{Institutional Capital on the Micro Level}

The definition of institutional capital on the micro level focuses on capital property and economic benefits. 
Table 1. Definition of institutional capital in existing literature.

\begin{tabular}{|c|c|c|}
\hline Perspective of the Definition & Core Content & Main References \\
\hline \multirow{6}{*}{$\begin{array}{l}\text { Micro perspective: Define } \\
\text { institutional capital as the input } \\
\text { that can create economic } \\
\text { income, from the angle of } \\
\text { corporate strategic management } \\
\text { and acqusition of } \\
\text { competitive adcantage. }\end{array}$} & $\begin{array}{l}\text { The environmental factors and capabilities that } \\
\text { embedded in the environment and support } \\
\text { value-added activities. }\end{array}$ & $\begin{array}{c}\text { Oliver, C. (1997), Smith, et al. (2008), } \\
\text { Lounsbury, M., Glynn, M. A. (2001), } \\
\text { Bresser, R., Millonig, K. (2003), } \\
\text { Reihlen, M. et al. (2010), } \\
\text { Yang, Z., Su, C. (2014), } \\
\text { Child, J., Marinova, S. (2014) }\end{array}$ \\
\hline & $\begin{array}{l}\text { Formal or informal institutional arrangements } \\
\text { or institutional structure of an economy. }\end{array}$ & $\begin{array}{l}\text { Hall, P. A., Soskice, D. (2001), } \\
\text { Platje (2007, 2008, 2011), } \\
\text { Leitch, J. (2012) }\end{array}$ \\
\hline & $\begin{array}{l}\text { A set of unique resources embedded in the } \\
\text { institutional environment. }\end{array}$ & Lu, Y. et al. (2010) \\
\hline & $\begin{array}{l}\text { Enterprises' resources, knowledge and } \\
\text { information that gained by taking } \\
\text { advantage of networks. }\end{array}$ & Gao, Y. (2015) \\
\hline & $\begin{array}{l}\text { Revenues obtained through corporate } \\
\text { profit-sharing, taking institution as inputs. }\end{array}$ & $\begin{array}{c}\text { Schultz, T. W. (1994), Picciotto, R. (1996), } \\
\text { Zhou, Y. M. (2003, 2013, 2014), } \\
\text { Yang, M. et al. (2013) }\end{array}$ \\
\hline & $\begin{array}{l}\text { A collection of written or unwritten behavioral } \\
\text { rules and social consensus built by } \\
\text { organization or set up } \\
\text { supported by the organization. }\end{array}$ & $\begin{array}{l}\text { Lin, N. (2005), } \\
\text { Hoff, K. and Sen, A. (2005) }\end{array}$ \\
\hline $\begin{array}{l}\text { Macro perspective: Define } \\
\text { institutional capital as } \\
\text { superiority resulting from } \\
\text { national economic institutions } \\
\text { and political institutions. }\end{array}$ & $\begin{array}{l}\text { National superiority or comparative } \\
\text { institutional advantage obtained } \\
\text { from certain economy. }\end{array}$ & $\begin{array}{l}\text { Healey, P. (1998), Wolsink, H. (1999), } \\
\text { Brunell, L. (2005), Chen, } \\
\text { Z. W. (2008), Schneider, M. R. (2010), } \\
\text { Lietaer, B., Hallsmith, G. (2011) }\end{array}$ \\
\hline
\end{tabular}

Institutional capital has been studied from different disciplinary perspectives like economics, sociology and organizational theory, etc. Oliver, C. (1997) defines institutional capital as environmental elements embedded in organizations' environment, which can enhance resource allocation capability; key success factor of institutional capital is effective resource management decision in certain institutional environment. In this sense, Oliver defines institutional capital both as “capability” and “institutional context”. Subsequent researchers quote Oliver's double definition of institutional capital and combine it with their own researches, which make it more and more difficult to form a consensus [11] [12].

1) Institutional capital is some kind of resource. Based on different theoretical foundation, scholars have formed different definitions of the concept. In the field of strategic management, Lu thinks that institutional capital as unique resources embedded in the external institutional environment based on RBV, which defines institutional capital as a type of heterogeneous resource that could bring sustainable competitive advantage for enterprises [13]. In the context of institutional economics, literatures emphasize characteristics of capital. A series of literatures of Zhou, Y. M. (2004, 2013) about institutional capital can be seen as typical examples [14] [15]. Institution as input factors involves in production and marketing process and creates opportunities for "profit” sharing. As an attempt to combine institutional economics with economic growth theory, Yang M (2013) et al. introduces endogenous institution into Solow model, which provides a new idea for the quantization of institutional capital [16].

In the field of sociology, Lin, N. (2005) also talks about institutional capital in his classic book "Social capital: A theory of social structure and action,” He believes institutional capital is capital related to mainstream ideology and power-identity and reflects socio-cultural knowledge and skills about relevant rules within the institutional field [17]. Hoff, K., Sen, J. (2005) regards institutional capital as mechanism shaped by shared values, norms, expectations, standards and values associated with attitudes and beliefs [18]. Resource capital seeks the most cost-efficient solution, while institutional capital selects legitimacy of the organization as a key priority [19] 
[20]. Sociological scholars pay attention to institution's cultural-cognitive elements and think that the essence of institutional capital is to seek legitimacy through cognitive consistency.

2) Institutional capital can be defined as abilities. Child, J., Marinova, S. (2014) think institutional capital refers to the ability that an enterprise can adapt to and management institutions of home country and host country to improve internationalization performance [21]. They think the determinant factor is a contextual combination of home country and host country. When political stability and institutional maturity of host country is similar with or worse than those of home country, enterprises are able to gain institutional capital in foreign direct investment.

3) Institutional capital can be defined as a situation or institution itself. Bresser, R. \& Millonig, K. (2003) notes that institutional capital is external or internal institutional context that contributes to establishment and enhancement of competitive advantage. Institutional capital can be divided into two types, one classification include cognitive capital, normative capital and regulative capital [22], another classification is external institutional capital and internal institutional capital, as shown in Figure 1.

Strategic decision makers overcome sunk costs and bring a competitive advantage for the enterprise by establishing cognitive psychology such as experience, preferences, cognitive inertia or innovation, this can create cognitive institutional capital. Organizations adapt institutional filter and institutional isolating mechanism to establish internal values and norms. If this internal institutional mechanism can match with efficiency-driven economic rationality, the organization is able to obtain extra competitive advantage, and this is so called normative institutional capital. Regulative institutional capital refers to support from organizations, relevant institutional role or favorable formal and informal regulative institution.

Many scholars define institutional capital as institution itself, some scholars think institutional capital is limited to formal institutions [23], and some include both formal and informal institutional arrangements [24]. Gao, Y. et al. (2015) divides institutional capital into formal and informal part [25], on the one hand, enterprises develop networks to make up for the absence and weakness of formal institutions [26] [27], the resources, knowledge and information acquired through relational network is informal institutional capital, on the other hand, favorable resources and various support from government can be defined as formal institutional capital.

\subsection{Institutional Capital on the Macro Level}

The definition of institutional capital in macro-level focuses on its description and application range. Brunell, L. (2005) studies institutional capital from the political sphere and divided institutional capital into two parts, one

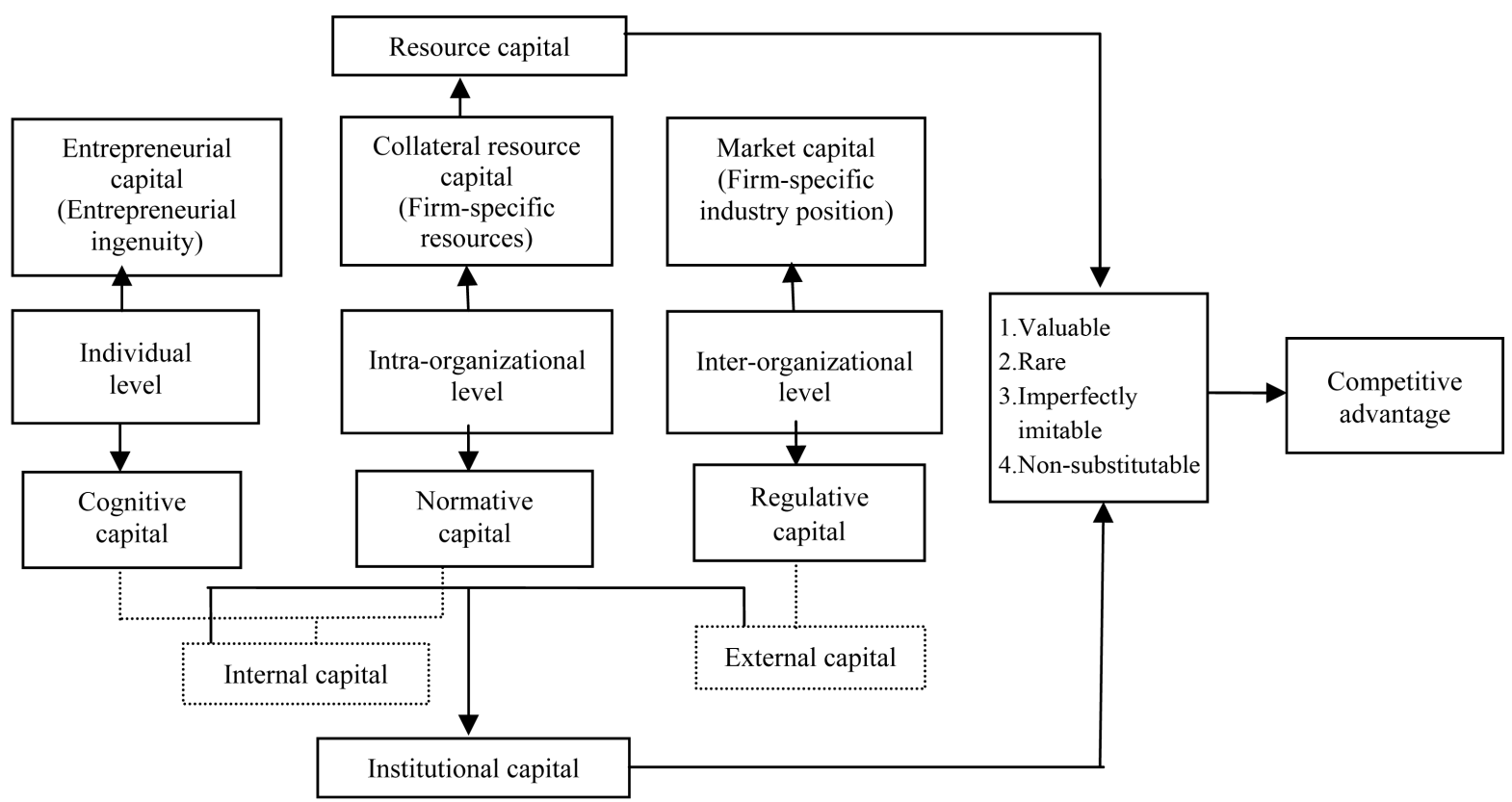

Figure 1. Relationship among institutional capital, resource capital and competitive advantage. Source: modified from Bresser, R. and Millonig, K. (2003). 
controlled by the state and other one controlled by civil society [28]. State-controlled institutional capital can promote effective use of resources and expertise of civil society by improving civic participation strategies and organizational forms. Civil society means that state's resources have been used by effective organizational forms and collective actions. Strong capabilities of private groups contribute to the increment of institutional capital. Platje, J. (2008) studies institutional capital for achieving sustainable development systematically and he believes institutional capital comes from four aspects [29]. The first is public domain, it is more likely to give rise to opportunistic and rent-seeking behaviors when the property is not clear, while explicit property rights will increase institutional capital and bring down transaction costs. The second is that economic system and governance structure can provide effective incentives for effective economic activities, which generates institutional capital. The third source is good governance associated with policy development and rule changes. The fourth point, when informal institution supports formal institution and two sides realize equilibrium, this balance generates capital [30]. Chen, Z. W. (2008) puts forward that institutional capital is a concept relative to institutional cost [31]. We can say a country owns high institutional capital when the state's institution is conducive to maximize the market and deepen the economic reform.

It is easy to tell that scholars have a variety of different interpretations towards the concept from different theoretical perspectives by reviewing the previous research. This paper argues that the creation of a new concept should fit the basic logic of the theoretical system it is going to enter, at the same time, the necessity and feasibility of abstracting experimental phenomenon should be examined. That is to say, certain empirical phenomena really need new nouns definition to abstract, which results in new concepts. On one hand, the concept of institutional capital should be considered as a kind of "capital", it must meet the essential connotation of "capital"; on the other hand, institutional capital is different from institution, if institution refers to a set of rules, norms or cognition, institutional capital could be seen as the economic value of rules, norms and cognition. As important production factors, rules, norms and cognitions could create income that exceed the original investment. Therefore, the definition of institutional capital should be distinguished from institution. Institutional capital in microlevel and macro-level are not contradictory because the concepts of social sciences are obtained by generalization and abstraction and the degree of generalization and level of abstraction are different [32]. Institutional capital is a comprehensive concept with multi factors and levels, which results in distinguished cognitive perspectives towards the concept. Learning from the formulation logic of institutional capital and the relationship between resources and capital: resources are potential capital and capital is resource to invest [33]. Considering Oliver taking institutional capital as equivalent concept of resource capital, the paper defines institution capital as the abilities to obtain economic benefits and competitive advantage by taking advantages of external and internal institutional environment.

\section{Characteristics of Institutional Capital as Source of Competitive Advantage Based on RBV}

To explore the source of competitive advantage, Wernerfelt, B. A. (1984) is the first one to develop theory of Penrose, E. T. (1959) in the strategic areas [34] [35]. He thinks that the key point of acquiring excess returns and maintaining competitive advantage is to accumulate internal organizational skills, resources and knowledge. Enterprises' internal resources play a decisive role in the creation of competitive advantage compared with external environment. Barney, Y. (1991) develops resource-based view (RBV) into a comprehensive theory which consider enterprises as a group of resource bundle that contains both tangible and intangible resources and he also proposes four criteria of strategic resources (valuable, scarcity, inimitability, non-substitutability) [36]. RBV researches explore the access to competitive advantage form the angle of resource selection and allocation, which provides us with a new perspective to observe the enterprise.

"Resource" within the range of RBV is a collective concept, the early researchers simply take tangible material resources into consideration and the scope of resources with further research has been expanding. Wernerfelt, B. A. (1984) defines resources as "anything that can be considered as advantages or disadvantages of a given enterprise. More formally, a company's resources can be defined as the permanent-owned (tangible and intangible) assets.” Brand, technical knowledge, highly-skilled employees, trade cooperation, machinery equipment, efficient program and capital can be seen as resources. Oliver, C. (1997) extends the scope of resources from internal to external environment, she thinks scarce flow of production, goodwill, patents, know-how tech- 
nology and institutional capital made up by different institutional actors such as customers, communities and governments can be seen as resources. As an input factor embedded in the institutional environment and contributes to formation of competitive advantages, institutional capital meets four criteria of heterogeneous strategic resources.

\subsection{Valuable Feature of Institutional Capital}

Capital increment is an essential requirement and inherent characteristics of capital. Capital in the modern sense is an important production element that could enhance value-adding activities and improve the level of social productive forces. As an intangible capital, increment is a primary attribute of institutional capital. Institutional capital can help organizations and the individuals make better decisions and adapt to institutional pressures easier by exerting influence on them, which leads to economic returns and increment. If implemented strategy can be interact with institutional environment effectively and create economic value higher than competitors through unique resources and activities, the process has fully reflected the valuable feature of institutional capital [37]. It's true that sometimes institution can restrain and limit people's behaviors and choices, but we should concern its encouraging and supporting role [38]. On one hand, institutional capital can promote efficiency and effectiveness to meet human needs as valuable productive assets [39]. On the other hand, institutional capital can help enterprise to nurture special non-market capacity as a strategic resource embedded in the environment, which will enhance enterprises’ dynamic responsiveness and economic performance [40].

\subsection{Rare Feature of Institutional Capital}

As a kind of resource allocation system, the most important role of institution is to reduce uncertainty from environment and collective action. On one side, institutional deficiencies or institution insufficiency will increase the risk of uncertainty and business operations. On the other side, overly complex institution will lead to increased transaction costs [41]. Institutional heterogeneity can create comparative advantages towards different subjects, rational institutional system can increase the momentum of economic entities and reduce cost of economic activity effectively. McMillan, J. (2007) proposes concept of market-supporting institution to describe an ideal institutional environment: protected property rights, observed commitments, suppressed externalities, positive competition and expedite information flow [42]. However, in the real economic life, good institution is always in short supply with respect to people's needs. In other words, institutional capital that can promote value-creating activities is a scarce element.

\subsection{Imperfectly Imitable Feature of Institutional Capital}

Economic value and scarcity of institutional capital will provide powerful incentive for competitors to imitate and copy. If institutional factors that embedded in internal and external environment can be easily copied, the competitive advantage will be no longer in existence. Similar with the logic of resource isolation mechanism, "institutional isolation mechanism" is appeared to stop enterprises from acquiring or copying some resources due to differences in the internal institutional environment, which hinder or isolate the flow of resources and have negative effects for competitive advantage. Traditional strategic management researchers emphasize the important role of unique historical environment on the enterprises' long-term performance [43] [44]. Corporate history and traditions are deeply imprinted in the business environment, which constitutes institutional capital and reduce the possibility of being imitated effectively. In the context of globalization and economic restructuring, significant segmentation in Chinese domestic market also create institutional capital by improving the dynamic response ability in complicated business environment, which is impossible for enterprises in other markets to imitate [45]. When connection between institutional environment and competitive advantage is vague, it is very difficult for other enterprises to enter or create a similar institutional environment and follow a successful business strategy. Institutional environment is often diverse, dynamic and even internal conflict, under the conditions of causal ambiguity, it is almost impossible to judge what kind of key elements in institutional environment create competitive advantages [46]. It is worth noting that institutional capital is a relative concept, different institutions prefer to different economic activities, which leads to contingency-oriented interaction between enterprises and institution [47]. Institutional capital can also transform into institutional cost in different organizational field, and this creates mobility barriers of institutional capital too. 


\subsection{Non-Substitutable Feature of Institutional Capital}

Resource capital is asset and competitiveness that can promote value-creation, while institutional capital can be seen as the context to maximize the effectiveness of resource capital. Besides favorable resource capital, institutional environment supporting economically rational decision-making is also indispensable. In other words, resource capital and institutional capital is non-substitutable. Institution can help organizations form legitimacy, resources and stability, which raises the possibility of organization's survival [48]. The main bodies in economic activity always look for resources from its cultural and institutional environment, when they define their own interests and developing strategies. Meyer. K. E. et al. (2009) finds that institutions and resources are not only complementary but also interdependent, entry strategy of enterprises implementing overseas expansion is the outcome of interaction between resources and institutions [49].

Seeing from resource-based view, institutional capital has all the features of heterogeneous resources that creating competitive advantages, so we can consider it as a unique resource embedded within the enterprises' environment. Value-creating and scarcity makes institutional capital an important source to create competitive advantage, while inimitability and non-substitutability makes it a basic foundation for sustaining competitive advantage. It is worth noting that institutional capital itself can't be translated into a competitive advantage directly. Institutional capital promotes enterprises’ particular abilities or strategic actions by matching internal and external environment to enhance enterprise performance and create competitive advantages.

\section{Measuring Method of Institutional Capital}

In terms of definition of institutional capital, Bresser, R., Molling, K. (2003) think that internal institutional capital includes cognitive and normative capital, while external institutional capital refers to regulative capital. However, the existing literatures that measure institutional capital do not follow this classification to operationalize. There are two types of measuring methods, one takes additional support gained from external institution, especially from government support, as the measuring method. The second gives point values to institutional characterization within the organization. The paper sorts the measurement of institutional capital from limited existing literatures and results are shown in Table 2.

\section{Future Research Prospect}

After combing the current definition of institutional capital, the paper discusses the relationship between institutional capital and competitive advantage from resource-based view. The mechanism to turn institutional capital into competitive advantage remains to be explored and to be tested empirically. Future research could focus on the following five aspects.

\subsection{Integration and Materialization of Institutional Capital}

By reviewing the literatures, we find that economics, organizational behavior, management, political science and other different disciplines have defined institutional capital, but various disciplines expand the extensions based on their own research needs, which makes the concept of institutional capital more complex and the theoretical boundary more blurred. These factors are not conducive to the further development and improvement of institutional capital. Therefore, it is worth considering whether we should build a unified theoretical framework to enhance the explanatory power of institutional capital. Some existing definitions have certain applicability, also show theoretical defects at the same time, which suggest that we should date from the theoretical root of institutional capital to maintain consistency and coherence of concept connotation.

\subsection{Establishment Process of Institutional Capital}

Although the institutional capital as a new source of competitive advantage has received lots of attention from scholars, but existing literatures study the formation mechanism based on definition and classification of institutional capital directly, instead of studying the acquisition or construction of institutional capital in depth. This processing mode actually simplifies the acquisition and construction mechanism of institutional capital, which can be confirmed from the current literature on its measurement and development. This paper argues that institutional capital is not born and should not be taken for granted. The acquisition of institutional capital requires 
Table 2. Measuring method of institutional capital.

\begin{tabular}{|c|c|c|c|}
\hline $\begin{array}{l}\text { Definition of } \\
\text { institutional } \\
\text { capital }\end{array}$ & $\begin{array}{c}\text { Research } \\
\text { method }\end{array}$ & Measurement index & Reference \\
\hline $\begin{array}{l}\text { Unique } \\
\text { resource } \\
\text { embedded in } \\
\text { institutional } \\
\text { environment }\end{array}$ & $\begin{array}{l}\text { Field } \\
\text { research }\end{array}$ & $\begin{array}{l}\text { Take number of government projects obtained by the enterprise to } \\
\text { measure institutional capital. A seven-level likert scale including three } \\
\text { aspects is adopted to measure the resources obtained from } \\
\text { governments and the state. The questionnaires are filled by the CEO or } \\
\text { corporate executives, focusing on the extent to which their } \\
\text { organizations: 1) access to government incentives in exports; 2) } \\
\text { participate in the exhibition to get support from } \\
\text { the local government; and 3) gain government support for } \\
\text { participating in domestic and overseas exhibitions. }\end{array}$ & Lu, et al. (2010) \\
\hline Legitimacy & $\begin{array}{l}\text { Desk } \\
\text { research }\end{array}$ & $\begin{array}{l}\text { Use single objective indicator to measure institutional capital, } \\
\text { named ISO certification. Taking ISO certification as set a } \\
\text { dummy variable, the paper assigns } 1 \text { to institutional } \\
\text { capital when the enterprise passes ISO certification, } \\
\text { and } 0 \text { when the enterprise did not pass. }\end{array}$ & $\begin{array}{l}\text { Zhang, Y. L, et al. } \\
\text { (2012) }\end{array}$ \\
\hline $\begin{array}{l}\text { Mechanisms } \\
\text { made up by } \\
\text { certain standards } \\
\text { and values }\end{array}$ & $\begin{array}{l}\text { Field } \\
\text { research }\end{array}$ & $\begin{array}{l}\text { Following the logic of commonality of values, integrity } \\
\text { of rules and effectiveness of mechanisms to design the } \\
\text { questionnaire and measure institutional capital form } \\
\text { these three aspects using a five-level likert scale. }\end{array}$ & $\begin{array}{c}\text { Jiang Y. J., } \\
\text { Zhang Y. R. (2013) }\end{array}$ \\
\hline $\begin{array}{l}\text { Capital } \\
\text { provided by } \\
\text { government or } \\
\text { private agencies }\end{array}$ & $\begin{array}{l}\text { Field } \\
\text { research }\end{array}$ & $\begin{array}{l}\text { The article defines } 15 \text { kinds of ways to obtain funds from } \\
\text { the government and private sectors. Respondents are asked } \\
\text { the ways in which they get money from the above funds, and } \\
\text { the frequency of obtaining the funds by using five Likert } \\
\text { scale ( } 1 \text { = not often; } 5 \text { = very frequently). Both the } \\
\text { existence and the valve of institutional capital are } \\
\text { measured in this paper. It assigns } 1 \text { to institutional capital } \\
\text { when the enterprise has gained funds from at least one way } \\
\text { and } 0 \text { when the enterprise never gets funds. It assigns } 0 \text { to } 15 \\
\text { to institutional capital according to the number } \\
\text { of ways in which the enterprise gets funds. }\end{array}$ & $\begin{array}{c}\text { Zhang J., } \\
\text { Howard V. A. (2011) }\end{array}$ \\
\hline $\begin{array}{l}\text { Value-adding } \\
\text { institutional } \\
\text { arrangements }\end{array}$ & $\begin{array}{l}\text { Desk } \\
\text { research }\end{array}$ & $\begin{array}{l}\text { Institutional capital of private entrepreneurs contains geopolitical } \\
\text { capital, cognitive capital, political capital and literacy capital. } \\
\text { 1) Entrepreneurs' geopolitical capital is measured by the } \\
\text { place in which the entrepreneurs is born and grow, } \\
\text { business location and political association. 2) Cognitive } \\
\text { capital is measured by the professional title, education } \\
\text { level and starting model of entrepreneurs. 3) Literacy } \\
\text { capital is measured by the age and military experience } \\
\text { of entrepreneurs. 4) Political capital is measured } \\
\text { by the political position and working years of entrepreneurs. }\end{array}$ & $\begin{array}{l}\text { Zhou Y. M., } \\
\text { Li X. J. (2013) }\end{array}$ \\
\hline
\end{tabular}

enterprises' efforts to take advantage of a series of external and internal environment and translate them into helpful capital. For example, the widely researched external regulative institutional capital is researched from two angles: an angle is capital brought by institutional environment itself. Government as the main character controls many important resources in the Chinese context [50]. Therefore, Institutional capital can be created by a series of favorable institutional arrangements, such as incentives and supporting measures, or obtain a variety of rents obtained because of close relationship with government. In this sense, institutional capital can be measured by the level of government support and government relations. Another angle is to obtain institutional capital by taking advantage of institutional diversity or institutional differences, during which the most typical approach is "institutional arbitrage" [51]. 


\subsection{Mechanism of Transforming Institutional Capital into Competitive Advantage}

The main reason of raising concept of institutional capital is to provide a new explanation for the source of competitive advantage, which is the logical basis for developing this concept. However, the process and mechanism that institutional capital creates competitive advantage remains to be explored. This paper argues that, according to the widely used SCP (structure-conduct-performance) pattern and RBV theoretical paradigm, there are at least two mechanisms that institutional capital can translate into competitive advantage. First, institutional capital affects enterprises' strategic behavior and then further affects competitive advantages. For example, some researches has paid attention to the influence of institutional factors towards industrial diversification, vertical integration, geographical diversification, mergers and acquisitions, internationalization, etc. Second, institutional capital affects enterprise capabilities, thereby affecting the competitive advantage. This paper thinks researches on relationship between institutional capital and competitive advantage can follow the framework shown in Figure 2, and promotes the process of conceptualization and operation by exploring the proper measurement scale. Furthermore, it is of great importance to carry out the empirical research on the relationship between institutional capital and competitive advantage in order to achieve a perfect match of theory and practice.

\subsection{Carrying out Empirical Research on Relationship between Institutional Capital and Competitive Advantage}

After analyzing specific mechanism on how institutional capital turns into competitive advantage, it is necessary to test and further explore it through empirical approach. Current views on competitive advantages can be divided into three categories, emphasizing on performance, value and ability respectively [52]. Different definitions lead to a wide range of metrics, it is very common to take performance as an indirect measure of competitive advantage in the actual study, specific indicators include investment return rate, sales profitability, growth rate, shareholder value and so on. Although the concept of institutional capital has been widely used in many fields, its conceptualization process is relatively slow, let alone converting to variable language. The current literatures expand the measurement of system capital based on their own research needs, which result in diversified measurement methods. Although many scholars agree that institutional capital can be broke down into three categories: cognitive capital, normative capital and regulative capital, but no one has taken it into reality yet in empirical studies, which is one direction of future researches.

\subsection{Localization of Institutional Capital}

Located in transitional economies and unique institutional environment, Chinese enterprises' institutional capital has greater influence on competitive advantage compared to enterprises in other markets. Chinese enterprises' competitive advantage not only comes from resource capital, variety of non-economic factors and non-market capabilities play a more important role. Institutional capital is of great value for researching internationalization, diversification and other strategic behaviors of Chinese enterprise to obtain competitive advantage and it is possible to extend the theoretical space of localization study as well as contextual theoretical research on

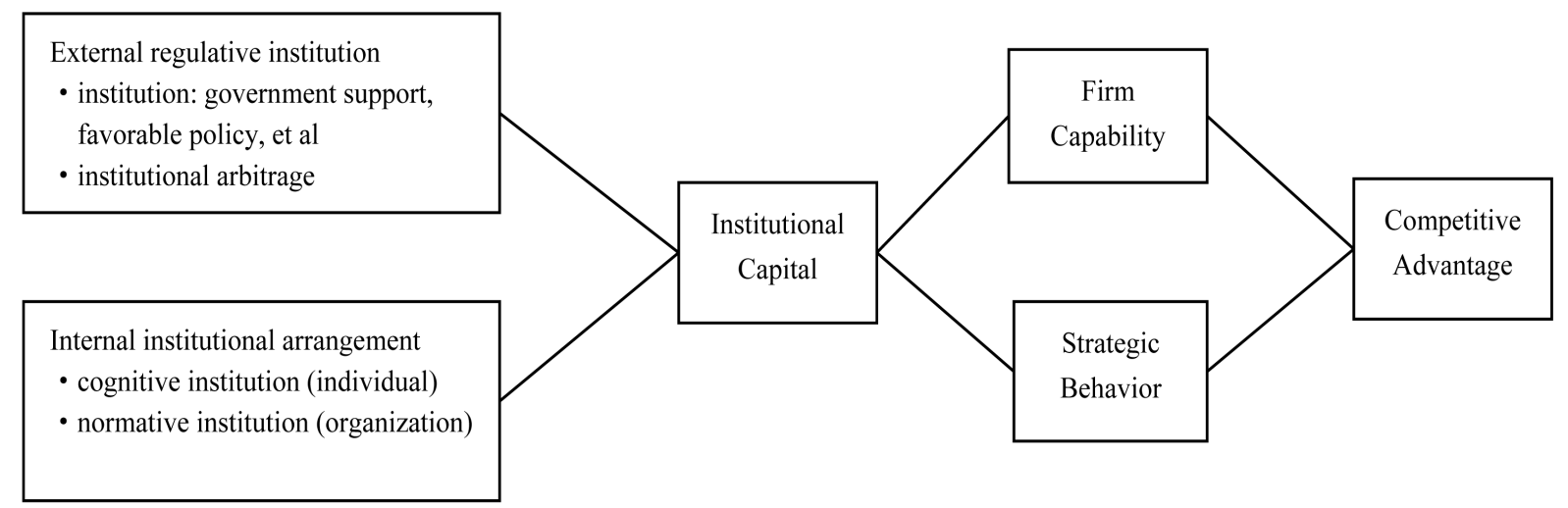

Figure 2. Logical framework of future research direction. 
Chinese enterprises [53].

\section{References}

[1] Porter, M.E. (2004) Competitive Advantage: Creating and Sustaining Superior Performance. Competitive Advantage Creating \& Sustaining Superior Performance, 1, 94.

[2] Rumelt, R.P. (1984) Towards a Strategic Theory of the Firm. Competitive Strategic Management, 26, 556-570.

[3] Barney, J.B. (1996) The Resource-Based Theory of the Firm. Organization Science, 7, 469. http://dx.doi.org/10.1287/orsc.7.5.469

[4] Poter, M.E. and Miliar, V.E. (1985) How Information Gives You Competitive Advantage.

[5] Peng, M.W., Sun, S.L. and Pinkham, B. (2009) The Institution-Based View as a Third Leg for a Strategy Tripod. The Academy of Management Perspectives, 23, 63-81. http://dx.doi.org/10.5465/AMP.2009.43479264

[6] Oliver, C. (1997) Sustainable Competitive Advantage: Combining Institutional and Resource-Based Views. Strategic Management Journal, 18, 679-713. http://dx.doi.org/10.1002/(sici)1097-0266(199710)18:9<697::aid-smj909>3.0.co;2-c

[7] Peng, M.W. (2002) Towards an Institution-Based View of Business Strategy. Asia Pacific Journal of Management, 19, 251-267. http://dx.doi.org/10.1023/A:1016291702714

[8] Bresser, R. and Millonig, K. (2003) Institutional Capital: Competitive Advantage in Light of the New Institutionalism in Organization Theory. Schmalenbach Business Review, 55.

[9] Schultz, T.W. and Theodore, W. (1968) Institution and the Rising Economic Value of Man. American Journal of Agricultural Economics. http://dx.doi.org/10.2307/1237297

[10] Brunell, L. (2005) Institutional Capital: Building Post-Communist Government Performance. University Press of America.

[11] Reihlen, M., Smets, M. and Veit, A. (2009) Management Consultancies as Institutional Agents: Strategies for Creating and Sustaining Institutional Capital. Academy of Management, 1, 1-6. http://dx.doi.org/10.5465/ambpp.2009.44247397

[12] Lounsbury, M. and Glynn, M.A. (2001) Cultural Entrepreneurship: Stories, Legitimacy, and the Acquisition of Resources. Strategic Management Journal, 22, 545-564. http://dx.doi.org/10.1002/smj.188

[13] Lu, Y., Zhou, L., Bruton, G. and Li, W. (2010) Capabilities as a Mediator Linking Resources and the International Performance of Entrepreneurial Firms in an Emerging Economy. Journal of International Business Studies, 41, 419436. http://dx.doi.org/10.1057/jibs.2009.73

[14] Zhou, Y.M. (2004) Institutional Capital Theory: A Framework of Institutional Analysis of Institutional Capital Theory. Journal of Yunnan University, 2, 43-49.

[15] Zhou, Y.M. (2013) Institution Dividends, Institutional Capital and Income Doubling. Henan Social Sciences, 21, 7-11.

[16] Yang, M., Ye, B. and Yang, F. (2013) Research on Economic Growth Model of Institution Endogenesis and Capitalization. Inquiry into Economic Issues, 3, 24-29.

[17] Lin, N. (2005) Social Capital: A Theory of Social Structure and Action. Century Press, Shanghai.

[18] Hoff, K. and Sen, A. (2005) The Kin System as a Poverty Trap? World Bank Policy Research Working Paper, 3575.

[19] Martinez, R.J. and Dacin, M.T. (1999) Efficiency Motives and Normative Forces: Combining Transactions Costs and Institutional Logic. Journal of Management, 25, 75-96. http://dx.doi.org/10.1177/014920639902500104

[20] Yang, Z. and Su, C. (2014) Institutional Theory in Business Marketing: A Conceptual Framework and Future Directions. Industrial Marketing Management, 43, 721-725. http://dx.doi.org/10.1016/j.indmarman.2014.04.001

[21] Child, J. and Marinova, S. (2014) The Role of Contextual Combinations in the Globalization of Chinese Firms. Management and Organization Review, 10, 347-371. http://dx.doi.org/10.1111/more.12073

[22] Scott, W.R. (1995) Institutions and Organizations. SAGE Publications, Thousand Oaks.

[23] Lietaer, B. and Hallsmith, G. (2011) Creating Wealth: Growing Local Economies with Local Currencies. New Society Publishers, Gabriola Island.

[24] Hall, P.A. and Soskice, D. (2001) Varieties of Capitalism: The Institutional Foundations of Comparative Advantage. Oxford University Press, Oxford. http://dx.doi.org/10.1093/0199247757.001.0001

[25] Gao, Y., Gao, S. and Zhou, Y. (2015) Picturing Firms’ Institutional Capital-Based Radical Innovation under China’s Institutional Voids. Journal of Business Research, 68, 1166-1175. http://dx.doi.org/10.1016/j.jbusres.2014.11.011

[26] Park, S.H. and Luo, Y. (2001) Guanxi and Organizational Dynamics: Organizational Networking in Chinese Firms. Strategic Management Journal, 22, 455-477. http://dx.doi.org/10.1002/smj.167 
[27] Peng, M.W. and Heath, P.S. (1996) The Growth of the Firm in Planned Economies in Transition: Institutions, Organizations, and Strategic Choice. Academy of Management Review, 21, 492-528.

[28] Bruell, L. (2005) Institutional Capital: Building Post-Communist Government Performance. University Press of America, Lanham.

[29] Platje, J. (2008) "Institutional Capital” as a Factor of Sustainable Development-The Importance of an Institutional Equilibrium. Technological and Economic Development of Economy, 14, 144-150. http://dx.doi.org/10.3846/1392-8619.2008.14.144-150

[30] Platje, J. (2008) An Institutional Capital Approach to Sustainable Development. Management of Environmental Quality: An International Journal, 19, 222-233. http://dx.doi.org/10.1108/14777830810856609

[31] Chen, Z.W. (2008) Why Hard-Working Chinese People Are Not Wealthy. CITIC Press, Beijing.

[32] Yang, F. and Wang, H.S. (1997) Social Research Methods. Peking University Press, Beijing.

[33] Liu, L.P. (2006) Corporate Social Capital: Self-Examination for the Concept and Measurement Approach. The Study of Sociology, 2, 204-216.

[34] Wernerfelt, B.A. (1984) Resource-Based View of the Firm. Strategic Management Journal, 5, 171-180. http://dx.doi.org/10.1002/smj.4250050207

[35] Penrose, E.T. (1959) The Theory of the Growth of the Firm. Oxford University Press, Oxford.

[36] Barney, J. (1991) Firm Resources and Sustained Competitive Advantage. Journal of Management, 17, 99-120. http://dx.doi.org/10.1177/014920639101700108

[37] Martin, X. (2014) Institutional Advantage. Global Strategy Journal, 4, 55-69. http://dx.doi.org/10.1111/j.2042-5805.2013.01072.x

[38] Scott, W.R. (2008) Approaching Adulthood: The Maturing of Institutional Theory. Theory and Society, 37, 427-442. http://dx.doi.org/10.1007/s11186-008-9067-z

[39] Shi, M.F. and Ke, W.G. (2000) Institutional Economics. Commercial Press, Beijing.

[40] Long, Y.A. (2013) An Empirical Study of the Effect of Non-Market Factors on China's Overseas Direct Investment. International Economics and Trade Research, 7, 8.

[41] Chan, C.M., Isobe, T. and Makino, S. (2008) Which Country Matters? Institutional Development and Foreign Affiliate Performance. Strategic Management Journal, 29, 1179-1205. http://dx.doi.org/10.1002/smj.705

[42] Mcmillan, J. (2007) Market Institutions. In: Durlauf, S.N. and Blume, L.E., Eds., The New Palgrave Dictionary of Economics, Second Edition, Palgrave Macmillan, London, 24-38.

[43] Learned, E.P., Christensen, C.R. and Andrews, K.R. (1969) Business Policy: Text and Cases. RD Irwin, Homewood.

[44] Ansoff, H.L. (1965) Corporate Strategy. McGraw-Hill, New York.

[45] Lan, H.L. and Pi, S.L. (2011) On Strategic Choices of Chinese Corporation under Dual-Condition of Economic Globalization and Market Fragmentation. Journal of Management, 8, 1107-1114.

[46] Greenwood, R., Oliver, C., Suddaby, R. and Sahlin-Andersson, K. (2008) The Sage Handbook of Organizational Institutionalism. Sage, London.

[47] Besharov, M.L. and Smith, W.K. (2014) Multiple Institutional Logics in Organizations: Explaining Their Varied Nature and Implications. Academy of Management Review, 39, 364-381. http://dx.doi.org/10.5465/amr.2011.0431

[48] Meyer, J.W. and Rowan, B. (1977) Institutionalized Organizations: Formal Structure as Myth and Ceremony. American Journal of Sociology, 83, 340-363. http://dx.doi.org/10.1086/226550

[49] Meyer, K.E., Estrin, S. and Bhaumik, S.K. (2009) Institutions, Resources, and Entry Strategies in Emerging Economies. Strategic Management Journal, 30, 61-80. http://dx.doi.org/10.1002/smj.720

[50] Wilkinson, T. and Brouthers, L.E. (2006) Trade Promotion and SME Export Performance. International Business Review, 15, 233-252. http://dx.doi.org/10.1016/j.ibusrev.2006.03.001

[51] Jackson, G. and Deeg, R. (2008) Comparing Capitalisms: Understanding Institutional Diversity and Its Implications for International Business. Journal of International Business Studies, 39, 540-561. http://dx.doi.org/10.1057/palgrave.jibs.8400375

[52] Zhang, J.W. and Wang, Y.J. (2010) Evaluation and Future Prospects for Competitive Advantage and Evolution. Foreign Economics and Management, 3, 1-10.

[53] Lan, H.L., Song, T.B. and Zeng, P. (2012) An Examination of Context Theorization Based on Chinese Corporate Strategic Management Practices. Chinese Journal of Management, 9, 12-16. 